\title{
Keratouveitis caused by Euphorbia milii sap: case report and overview
}

Ceratouveíte causada pela seiva de Euphorbia millii: relato de caso e visão geral

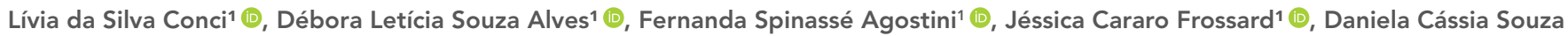
Alves $^{2}$ (]), Danilo Henrique Souza Alves ${ }^{2}$ (), Alexandre Grobbério Pinheiro ${ }^{1}$ (])

Keywords:

Eye injuries; Uveitis, anterior; Keratitis; Euphorbia

Descritores:

Traumatismos oculares; Uveíte anterior; Ceratite; Euphorbia

Received on: Jan 01, 2020

Accepted on: Aug 10,2021

Corresponding author: Débora Letícia Souza Alves Avenida Marechal Campos, 1.355, Setor da Visão, Casa 4 - Santa Cećlia, Zip code: 29043-260 - Vitória, ES, Brazil. E-mail: debora_Isa@hotmail.com

Institution: Universidade Federal do Espírito Santo

Conflict of interest: no conflict of interest.

Financial support: no financial support for this work.

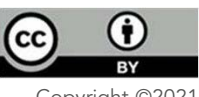

Copyright (C2021

\section{ABSTRACT}

Objective: To report a case of anterior uveitis caused by Euphorbia milii sap and review all reported cases of keratouveitis related to this species.

Methods: A 64-year-old male patient presented with a 10-day history of reduced visual acuity, pain, and photophobia in the left eye after an accidental contact with Euphorbia milii sap. Best-corrected visual acuity was initially 20/200. Upon examination, ciliary injection, mild corneal edema; fine keratic precipitates, and significant anterior chamber reaction. There was no vitritis, and fundoscopy was unremarkable. The patient initiated on topical steroid and tropicamide.

Results: Best-corrected visual acuity in left eye improved to 20/20 after using eyedrops for 3 weeks, associated with complete resolution of anterior uveitis. Over the following 6 months, best-corrected visual acuity remained stable, and no evidence of recurrent inflammation was observed.

Conclusion: To the best of our knowledge, this is the third reported case of keratouveitis caused by Euphorbia milii sap. As observed in other cases of keratouveitis caused by sap of this species, the clinical course is benign and characterized by moderate reaction of the anterior chamber, and corneal involvement of variable intensity.

\section{RESUMO}

O objetivo foi relatar um caso de uveíte anterior induzida pela seiva da Euphorbia milii e revisar todos os casos relatados de ceratouveíte causados por essa espécie. Paciente do sexo masculino, 64 anos, apresentou história de 10 dias de evolução com redução da acuidade visual, dor e fotofobia no olho esquerdo, após contato acidental com a seiva da planta Euphorbia milii. A acuidade visual com melhor correção era inicialmente 20/200. O exame revelou injeção ciliar, edema de córnea leve, precipitados ceráticos finos e reação de câmara anterior significativa. Não havia vitreíte, e a fundoscopia não exibia alterações. Foram iniciados colírios de esteroides e tropicamida. A acuidade visual no olho esquerdo melhorou para 20/20 em 3 semanas com a utilização dos colírios, além de se ter alcançado a resolução completa da uveíte anterior. Nos 6 meses seguintes, a acuidade visual permaneceu estável, e não foi observada evidência de recorrência da inflamação. Até então, este é o terceiro caso relatado de ceratouveíte pela seiva da Euphorbia milii. Como visto nos demais casos de ceratouveíte induzidos pela seiva dessa espécie, o curso clínico é benigno e caracterizado por reação moderada da câmara anterior, com envolvimento corneano de intensidade variável. 


\section{INTRODUCTION}

Euphorbia is a giant genus including approximately 2,000 species, remarkable for its great morphological variability, including a wide range of life forms, from small herbs to trees, as well as succulents. Species of this genus grow in all five continents and they are commonly employed as ornamental plants. ${ }^{(1)}$

It is known that the sap of many Euphorbia plants may be toxic to both skin and eye on contact. ${ }^{(2)}$ Guggenheim et al. reported the first case of eye injury caused by Euphorbia sap, in 1926. ${ }^{(3)}$ Since then, several cases have been described and the spectrum of damage ranges from mild conjunctivitis to corneal ulcer, and even uveitis. ${ }^{(4)}$

The objective was to report a case of anterior uveitis caused by E. milii sap, and review all reported cases of keratouveitis caused by this species. To our knowledge, this is the third documented case of keratouveitis caused by E. milii sap.

\section{CASE REPORT}

A 64-year-old man presented with a 10-day history of blurred vision, pain, and photophobia in his left eye (LE), after contact with sap of Crown of Thorns (Euphorbia milii) (Figure 1A). He reported an accidental plant sap leakage toward his LE, when he was pruning the plant at home. Since it caused immediate pain, he promptly irrigated the eye with water. His review of systems disclosed only controlled hypertension and he denied any relevant past ocular history.

On examination, his best corrected visual acuity (BCVA) was 20/20 in the right eye (RE) and 20/200 in the LE. In LE, biomicroscopy revealed discrete ciliary injection, mild corneal edema, fine keratic precipitates, flare, and significant cell anterior-chamber reaction $(3+/ 4)$ (Figures 1B, 1C and 1D). Sodium fluorescein dye did not stain any corneal ulceration, just inferior punctate keratitis. Intraocular pressure was $18 \mathrm{mmHg}$ in $\mathrm{RE}$ and 28 $\mathrm{mmHg}$ in LE. There was no vitritis and fundoscopy was unremarkable in both eyes.

The patient was treated with topical prednisolone acetate $(1 \%)$ in association with tropicamide (1\%) eye drops. Best corrected visual acuity in his LE improved to 20/20 after 3 weeks using the eye drops, with complete resolution of anterior uveitis. Biochemical workup and systemic evaluation were negative for other potential causes of anterior uveitis. Over the following 6 months, BCVA remained stable, and no evidence of inflammation recurrence was observed.

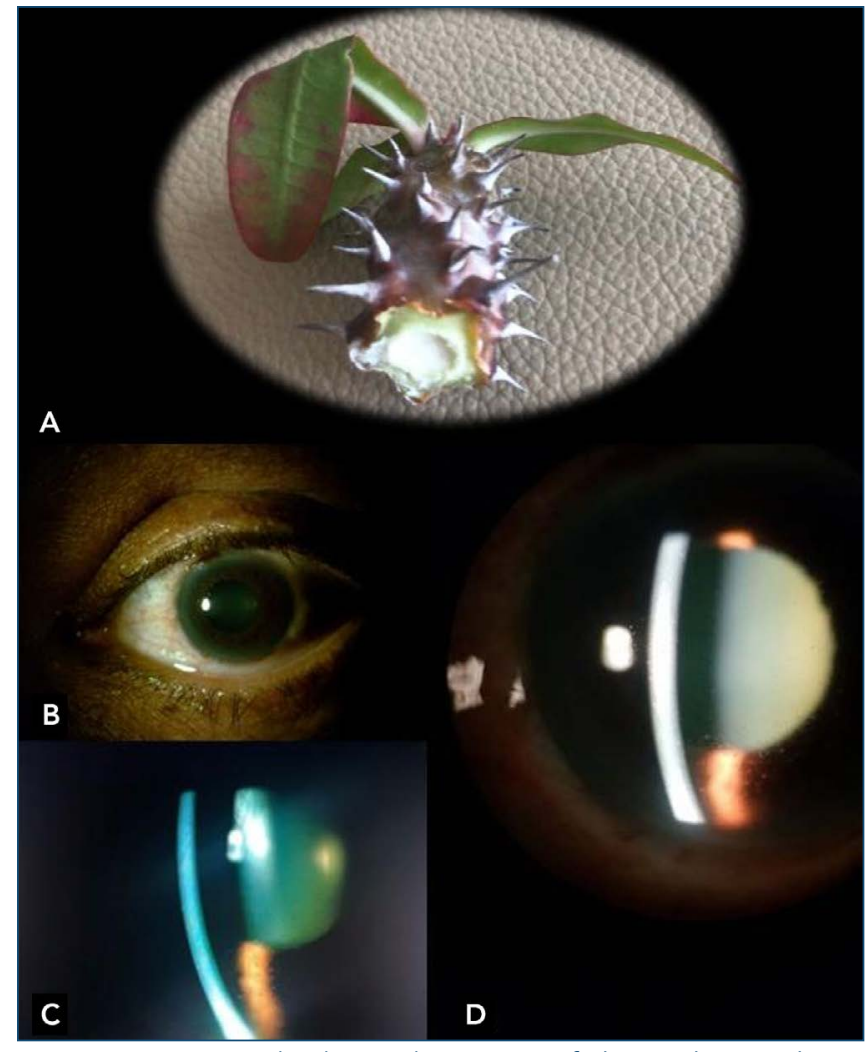

Figure 1. (A) Euphorbia milii (crown of thorns houseplant). ( $B, C$ and D) Discrete ciliary injection, mild corneal edema, fine keratic precipitates, and cell anterior-chamber reaction, 10 days after exposure to E. milii sap.

\section{DISCUSSION}

A literature review showed in most cases of ocular toxicity by Euphorbia there was immediate pain, conjunctival injection, epithelial ulceration, and corneal edema. In addition, epiphora, lid swelling, photophobia, chemosis, and anterior-chamber inflammation were also common manifestations. ${ }^{(5)}$ There are no reports of posterior segment involvement. Visual loss is a delayed feature, occurring 24 hours after eye contact. ${ }^{(6)}$ In our case, immediate pain, photophobia, conjunctival injection, corneal edema, and anterior chamber inflammation were observed.

The clinical manifestations can be explained by composition of Euphorbia latex: phenols, alkaloids and sesquiterpene lactones are liposoluble and can penetrate epithelial cellular membranes and the anterior chamber. ${ }^{(6)}$ Interestingly, corneal epithelial defects may require several days to heal. It can be justified by the antineoplastic effects of some components, such as ingenol 3,20-dibenzoate, present in Euphorbia esula sap. ${ }^{(4)}$

Severe keratouveitis has been associated with exposure to the sap of several Euphorbia species, including lactea, royleana, lathyris, trigona, tirucalli, peplus, cyparissias, helioscopia and grandicornis. ${ }^{(4,5,7,8)}$ It is noteworthy that 
Table 1. Clinical characteristics of keratouveitis induced by Euphorbia millii sap

\begin{tabular}{|c|c|c|c|c|c|c|c|c|c|c|c|}
\hline Author & $\begin{array}{l}\text { Time to } \\
\text { presentation }\end{array}$ & $\begin{array}{l}\text { Corneal } \\
\text { edema }\end{array}$ & Epithelial deffect & $\begin{array}{l}\text { Anterior } \\
\text { chamber } \\
\text { reaction }\end{array}$ & $\begin{array}{l}\text { Intraocular } \\
\text { pressure }\end{array}$ & $\begin{array}{c}\text { Topical } \\
\text { antibiotic }\end{array}$ & $\begin{array}{l}\text { Topical } \\
\text { mydriatic }\end{array}$ & $\begin{array}{l}\text { Topical } \\
\text { steroid }\end{array}$ & $\begin{array}{c}\text { Initial } \\
\text { VA }\end{array}$ & Final VA & $\begin{array}{l}\text { Time for } \\
\text { uveitis } \\
\text { resolution }\end{array}$ \\
\hline Eke, $2000^{(4)}$ & 4 hours & Present & $\begin{array}{l}\text { Loss of central } \\
\text { corneal } \\
\text { epithelium }\end{array}$ & $1-2+/ 4$ & $16 \mathrm{mmHg}$ & Yes & Yes & Yes & $20 / 200$ & $\begin{array}{l}\text { 20/80 (concomitant age } \\
\text { macular degeneration) }\end{array}$ & 2 weeks \\
\hline Basak, $2009^{(9)}$ & 4 hours & Present & Punctate Keraritis & $2+/ 4$ & $14 \mathrm{mmHg}$ & Yes & Yes & Yes & $20 / 120$ & $20 / 20$ & 2 weeks \\
\hline Present case, 2021 & 10 days & Present & Punctate Keraritis & $3+/ 4$ & $28 \mathrm{mmHg}$ & No & Yes & Yes & $20 / 200$ & $20 / 20$ & 3 weeks \\
\hline
\end{tabular}

the degree of ocular inflammation seems to be related with different species. ${ }^{(4)}$ For example, Euphorbia peplus causes a typical keratopathy with fibrinous anterior uveitis, while Euphorbia lathyris has a similar clinical course, but with mild uveitis and there is no fibrin. On the other hand, Euphorbia characias does not cause uveitis. ${ }^{(4)}$

Regarding to E. milii, there are only two previous reported cases of keratouveitis caused by this specie. Their clinical characteristics are displayed in Table 1. What mainly differs our case from those is the elevated intraocular pressure $(28 \mathrm{mmHg}$ ) and the late presentation of the patient (10 days of history). However, in all three cases, corneal edema, epithelial defects (varying from punctate keratitis to severe central epithelial defect) ${ }^{(4,9)}$ and moderate anterior chamber reaction were observed. All of them were treated with topical steroids associated with mydriatic agents, which led to resolution of inflammation within a few weeks. In our case, there was no significant epithelial corneal defect, therefore topical antibiotic was not initiated, unlike other cases. ${ }^{(4,9)}$ The clinical course was benign, with total visual recovery in all three cases, including ours, which had a delayed presentation and, subsequently, late treatment.

In conclusion, keratouveitis caused by E. milii is an uncommon eye disorder and it is characterized by moderate anterior chamber reaction and corneal involvement of variable intensity. The final visual outcome of keratouveitis in our case was favourable, as it was in the two previous reports, despite some differences in time to presentation and treatment.

\section{REFERENCES}

1. Horn JW, van Ee BW, Morawetz JJ, Riina R, Steinmann VW, Berry PE, et al. Phylogenetics and the evolution of major structural characters in the giant genus Euphorbia L. (Euphorbiaceae). Mol Phylogenet Evol. 2012;63(2):305-26.

2. Schmidt RJ, Evans FJ. Skin irritants of the sun spurge (Euphorbia helioscopia L.). Contact Dermat. 1980;6(3):204-10.

3. Guggenheim I. [Bindehaut und horntentzundung surch saft der E. helioscope]. Klin Monatsbl Augenheilkd. 1926;77: 521-3. German.

4. Eke T, Al-Husainy S, Raynor MK. The spectrum of ocular inflammation caused by euphorbia plant sap. Arch Ophthalmol. 2000;118(1):13-6.

5. Merani R, Sa-Ngiampornpanit T, Kerdraon Y, Billson F, McClellan KA. Euphorbia lactea sap keratouveitis: case report and review of the literature. Cornea. 2007;26(6):749-52.

6. Shields MK, Andrew NH, LaHood BR, Saha N. Eye injuries following ocular exposure to euphorbia plant sap: an Australian and New Zealand case series. Clin Exp Ophthalmol. 2018;46(4):434-7.

7. Scott IU, Karp CL. Euphorbia sap keratopathy: four cases and a possible pathogenic mechanism. Br J Ophthalmol. 1996;80(9):823-6.

8. Gómez-Valcárcel M, Fuentes-Páez G. Euphorbia grandicornis Sap Keratouveitis: A case report. Case Rep Ophthalmol. 2016;7(1):125-9.

9. Basak SK, Bakshi PK, Basu S, Basak S. Keratouveitis caused by euphorbia plant sap. Indian J Ophthalmol. 2009;57(4):311-3. 